\title{
Free Protein S Measurement
}

National Cancer Institute

\section{Source}

National Cancer Institute. Free Protein S Measurement. NCI Thesaurus. Code C122142.

The determination of the amount of unbound protein $\mathrm{S}$ in a biological specimen. 